\title{
PATROLLING THE BORDERS OF THE EU LEGAL ORDER: CONSTITUTIONAL REPERCUSSIONS OF THE KADI JUDGMENT
}

\begin{abstract}
Jan Willem van Rossem*
Summary: The recent Kadi judgment, in which the ECJ invalidated a Community regulation implementing a SC sanction resolution on account of a violation of EU fundamental rights, in several ways constitutes a landmark constitutional ruling. Particularly noteworthy are the Court's pronouncements on the relationship between EU law and international law. Central to this reasoning is the principle of autonomy of the Community legal order. Departing from this concept, the ECJ in Kadi seems to draw a sharp and impermeable line between 'domestic' EU law and 'external' UN law. For this allegedly strong dualist approach, the Court has been severely criticised. This paper will examine to what extent this criticism is justified. It comes to the conclusion that if the premise of an autonomous legal order is accepted, the choices made by the ECJ in Kadi were legitimate. In addition, this article inquires how the Court's approach relates to the concept of constitutional pluralism, which is very much in vogue today as an explanatory framework for the foundations of the European legal order. It is submitted that Kadi is hard to reconcile with this paradigm.
\end{abstract}

\section{Introduction}

On 3 September 2008, the European Court of Justice (ECJ) issued a ruling that even before it was handed down was destined to become an instant classic of EU law: Kadi and Al Barakaat $v$ Council. ${ }^{1}$ In Kadi, the Court partially annulled a Community regulation, enacted in reference to a common position under the Common foreign and security policy (CFSP) of the European Union (EU), which implemented a Security Council (SC) resolution designed to freeze funds of individuals and organisations associated with terrorist networks. ${ }^{2}$ Whereas the Court of First Instance (CFI) had initially rejected this claim, ${ }^{3}$ the ECJ found the sanction measure to

\footnotetext{
"Department of Constitutional and International Law, Faculty of Law, University of Groningen.

1 Joined Cases C-402/05 P and C-415/05 P Yassin Abdullah Kadi and Al Barakaat International Foundation $v$ Council and Commission [2008] nyr.

2 See especially Council Regulation (EC) no 881/2002, OJ 2002, L 139/9; Common Position 2002/402/CFSP, OJ 2002, L 139/4; S/RES/1267 (1999) of 15 October 1999.

3 Case T-315/01 Yassin Abdullah Kadi v Council and Commission [2005] ECR II-3649;
} 
be in breach of certain fundamental rights guaranteed under EU law. ${ }^{4}$ The judgment, which was delivered against the background of the global war on terror, constitutes a potent cocktail of some of the most highly profiled and contested issues of the European constitutional debate. The three main topics were community competence, the reception of international law in the EU legal order, and the protection of fundamental rights. Of these issues, what probably attracted most attention were the Court's pronouncements on the relationship between EU law and international law. It is this subject that will be the focus of this paper. ${ }^{5}$

Kadi has been hailed as an important marker in the development of human rights protection, ${ }^{6}$ and, correspondingly, as a clear signal that this kind of safeguarding should be sped up at the level of the UN. ${ }^{7}$ Nonetheless, the judgment also received a good deal of criticism. Leading scholars on European constitutional law such as Gráinne de Búrca and Joseph Weiler have condemned the ruling as being 'parochial' in tone and lacking in judicial integrity. ${ }^{8}$ As the term 'parochial' implies, the cause of this critique lies not so much in the actual outcome of the case, but in the way the ECJ in Kadi carves out a place for the EU in the international legal order. In arriving at the conclusion that the contested regulation violated primary EU law, it effectively fenced off the Union legal order from the international plane. In contrast to the CFI, which had considered the case

Case T-306/01, Ahmed Ali Yusuf and Al Barakaat International Foundation v Council and Commission [2005] ECR II-3533.

4 More specifically, the applicants in Kadi, a Saudi Arabian and a Swedish national, argued that the regulation, under which they were listed as suspected terrorists, violated their right to respect for property, their right to be heard and their right to effective judicial review.

5 Although technically not always correct, this paper will not critically discern between the terms EU and EC.

6 See Takis Tridimas, 'Terrorism and the ECJ: Empowerment and Democracy in the EC Legal Order' (19 March 2009) Queen Mary School of Law Legal Studies Research Paper No $12 / 2009$ <http://ssrn.com/abstract=1365385>.

7 As matters currently stand, the task of overseeing the execution of terrorism sanctions is primarily the responsibility of the UN Sanctions Committee, an ancillary organ of the SC. The Sanctions Committee is supported by the Analytical Support and Sanctions Monitoring Team, which comments on the activities of the former. Listing and de-listing mechanisms at the level of the UN, centred on the Sanctions Committee, are predominantly diplomatic in nature. Even though the SC, after persistent criticism that had arisen even before the ECJ's judgment in Kadi, introduced some innovations to the review procedure of listings in two subsequent resolutions (S/RES/1730 (2006) of 19 December 2006 and S/RES/1822 (2008) of 30 June 2008), there is no quasi-judicial reviewing body present that might diminish concerns of due process rights violations. According to the Monitoring Team in its ninth and latest report (S/2009/245 paras 17-18), there is no need to establish such an organ, as domestic courts that have stepped in, such as the ECJ, can help the Sanctions Committee to strengthen the sanctions regime.

8 See Gráinne de Búrca, The European Court of Justice and the International Legal Order after Kadi Jean Monnet Working Paper No 1/09 <http://www.jeanmonnetprogram.org/papers/09/090101.html>; 'Editorial', (2009) 19 European Journal of International Law 895. 
chiefly through the prism of international law, the ECJ focused on the domestic law of the EU.

Key to the Court's self-referential treatment of the problem that it saw itself confronted with in Kadi was the principle of autonomy of the EU legal system. As is well-known, this paradigm, which the ECJ elaborated almost half a century ago in the seminal cases Van Gend \& Loos and Costa/ENEL, ${ }^{9}$ together with the related notions of direct effect and supremacy, serves as the foundation stone of EU constitutional doctrine. Despite the time that has elapsed since its invention, the concept of autonomy, due to questions surrounding the principle's conceptual feasibility, retains a somewhat axiomatic status. In view of the important ramifications of the Kadi judgment, however, it seems justified to reconsider the principle. Not surprisingly, such an inquiry is triggered by a case involving the relationship between EU and international law. Questions on ultimate authority often reveal themselves at the border of legal orders. Within the broader European legal order, theoretical disagreement on the exact rationale behind their demarcation notwithstanding, these borders are increasingly transparent. At the same time, however, the ECJ's stance in Kadi may shed light on a proper conception of the internal constellation of the EU. For one thing, a strong emphasis on autonomy seems to be at odds with the celebrated pluralistic nature of the Union legal structure.

Along these lines, this paper will argue that in one sense the Kadi reasoning on the relationship between European and international law follows logically from the ECJ's broader doctrine on the autonomous nature of EU law. It submits, however, that at another level and in view of the pluralistic set-up of the EU, the ruling raises conceptual questions that normally do not arise so overtly. Indeed, in attempting to live up to the very principles it had designed in order to create a veritable 'Community of law', the ECJ in Kadi at the same time paradoxically seems to cast doubt on the credibility of the EU's pluralistic sui generis nature. To assess this argument, the paper will first discuss the concept of autonomy, and link this to theories regarding sovereignty and pluralism. Next, it evaluates the function and place of the principle in Kadi. This is followed by an appraisal of the possible conceptual repercussions of the ruling and its meaning for the internal machinery of the Union. The paper will conclude by asking whether Kadi could have been decided in a different way.

9 Resp. Case 26/62 Van Gend \& Loos v Nederlandse Administratie der Belastingen [1963] ECR 1; Case 6/64 Costa v ENEL [1964] ECR 585. 


\section{Autonomy and pluralism}

By putting a strong emphasis on the autonomy the EU legal order, the ECJ in Kadi stressed that international law cannot affect the internal allocation of powers. ${ }^{10}$ The Court linked this perception with the familiar statement that the EU is based on the rule of law, ${ }^{11}$ first explicitly put forward in the often cited Les Verts case. ${ }^{12}$ In combination, it can be inferred from the decision that these precepts forced the ECJ to the conclusion that 'the obligations imposed by an international agreement cannot have the effect of prejudicing the constitutional principles of the EC Treaty (...)'. ${ }^{13}$ Consequently, it could only measure the contested regulation against the EU's own framework of norms. In doing so, the Court adopted a view that most lawyers would label dualist. ${ }^{14}$ This can be said to attest to a vision according to which the EU and international law belong to separate legal orders. ${ }^{15}$ To phrase it differently: the Court's position in Kadi is founded on the premise that the EU draws from a source different from international law. Thus, in the opinion of the ECJ, legally speaking the world appears to be a fragmented place, in which there is no single point of authority to adhere to.

The attitude of the ECJ vis-à-vis the international legal order stands in sharp contrast to the manner in which it views the internal legal order of the EU. Here, the Court basically negates the validity of a dualist approach. And, significantly, the principle of autonomy serves as an instrument to accomplish this negation, since the ECJ asserted the autonomous nature of the Community in Van Gend \& Loos and Costa/ENEL with a clear goal in mind: to establish the notions of direct effect and supremacy, bedrock pillars of the EU's special constitutional construction. However, arguably, the principle did not constitute a necessary precondition for the tenability of these concepts. ${ }^{16}$ Instructive in this regard is the Opinion in Costa of A-G Lagrange, who maintained that it was perfectly feasible to ground direct effect and supremacy in member-state constitutional doctrine. ${ }^{17}$ Possibly, therefore, the principle of autonomy was initially primarily meant to convince interlocutors at a national level.

\footnotetext{
10 Kadi (n 1) para 282.

11 Kadi (n 1) para 280.

12 Case 294/83 Parti Ecologiste 'Les Verts' v Parliament [1986] ECR 1339 para 23.

13 Kadi (n 1) para 285.

14 See text at n 57-59.

15 Kadi (n 1) paras 281 and 317. See also de Búrca (n 8) 42.

16 See Bruno de Witte, 'Direct Effect, Supremacy, and the Nature of the Legal Order' in Paul Craig and Gráinne de Búrca (eds), The Evolution of EU Law (OUP, Oxford 1999) 177-183.

17 Costa/ENEL at 620-623 of the Opinion of A-G Lagrange.
} 
In Van Gend \& Loos and Costa/ENEL, the ECJ - and with it the EU - embarked on a journey which, along the way, has been recognised as a crossing towards 'constitutionalisation' of the Treaties. As has been famously described by Joseph Weiler, this has involved an intricate, dialectical process between law and politics. ${ }^{18}$ In the course of this process, two aspects have been crucial: first, the initial merging of a supranational, functional posture at a juridical level with an intergovernmental approach in politics; secondly, the ECJ furnishing this combination with legitimacy by polishing it with the insertion of rule-of-law requirements. ${ }^{19}$ As a result, for a long time the Court's theoretical foundation of European integration, the autonomous nature of the Treaties, was never seriously questioned as such. While the EU continued to be gradually impregnated by this type of 'low-intensity constitutionalism'20 - not to mention the complicity in this process, by way of the preliminary reference procedure, of national courts - the issue simply did not come up in an explicit way. ${ }^{21}$ When the subject eventually did emerge - in the early 1990s, following the Single European Act and the Treaty of Maastricht - the EU's claim to normative authority, inherent in Van Gend \& Loos and Costa/ENEL, was already well established. Subsequently, acts of resistance stemming from national courts, most notably the German Bundesverfassungsgericht, mainly amounted to a certain status quo. ${ }^{22}$

What were these misgivings? In hindsight, one can say that they originated from a loss of influence on the part of the Member States who, in the new Treaties in many instances, lost their veto power, coupled with an expansion of EU competences. ${ }^{23}$ Thus, state sovereignty resurfaced as an issue on the European agenda. According to the German Constitutional Court, its resistance was principally caused by a concern for democracy, the inseparable nexus of the concept of sovereignty in nationstate doctrine. Judging that the EU suffered from a legitimacy problem, it consequently argued in its notorious Maastricht ruling that the EU was

18 JHH Weiler, 'The Transformation of Europe' (1991) 100 Yale Law Journal 2403. See also Miguel Poiares Maduro, 'The Importance of Being Called a Constitution: Constitutional Authority and the Authority of Constitutionalism' (2005) 3 International Journal of Constitutional Law 332.

19 Cf Maduro (n 18) 334-340, arguing at 337 that '(i)n the process of European integration, constitutionalism as the prevailing form of power followed the claim of normative authority and not vice versa'.

20 Maduro (n 18) 340-343.

21 Even with the first sparks of resistance against the path of the Court, which erupted in the 1970s, the emphasis was not so much on the alleged autonomous nature of the Community, but on the related claim to supremacy and on the quality of the rule of law in the Community legal order. See, most notably, BVerfGE 37, 271 [1974] (Solange I).

22 BVerfGE 89, 155 [1994] (Maastricht). See, more recently, eg the ruling of the Polish Constitutional Tribunal of 11 May 2005, Case K 18/04 (Accession Treaty).

23 See $\mathrm{n} 18$. 
still essentially to be seen as some kind of international organisation, a Staatenverbund. ${ }^{24}$ This in turn meant that the autonomy of the EU could only have a derivative nature and that the Karlsruhe Court had the ultimate power to declare European measures void on German soil. Although it never explicitly contradicted the German decision, it seems to be clear, however, that this is not what the ECJ had in mind. For one thing, the Court has repeatedly declared that EU law functions independently of the law of the Member States, even if this has a constitutional character: the validity of a European norm can only be judged in the light of EU law itself. ${ }^{25}$ Still, this does not justify the ECJ's claim to normative authority. It also does not explain how an autonomous Union relates to constituent parts that equally claim to have independent legal foundations.

The obvious place to look for answers is in Van Gend \& Loos and Costa/ENEL. As will be recalled, the Court in Van Gend \& Loos asserted that the

Treaty is more than an agreement which merely creates mutual obligations between the contracting states ... the Community constitutes a new legal order of international law for the benefit of which the states have limited their sovereign rights, albeit within limited fields, and the subjects of which comprise not only Member States but also their nationals. ${ }^{26}$

A year later, in Costa, it added:

By contrast with ordinary international treaties, the EEC Treaty has created its own legal system ... the law stemming from the treaty, an independent source of law, could not, because of its special and original nature, be overridden by domestic legal provisions, however framed, without being deprived of its character as community law and without the legal basis of the Community itself being called into question. ${ }^{27}$

What to make of this? Both rulings provide complementary and, in some respects, also different rationales. ${ }^{28}$ Noteworthy in particular in Van

\footnotetext{
24 BVerfGE 89, 155 (181). The Bundesverfassungsgericht has recently affirmed this position in its judgment on the constitutionality of the Lisbon Treaty. Although the Court in Lissabon adopts a more friendly tone towards the process of European integration than it did in Maastricht - it speaks of the Europarechtsfreundlichkeit of the German constitution - the core elements of its Maastricht reasoning remain intact. See BVerfGE, 2 BvE 2/08 of 30 June 2009 225-229.

25 See eg Case 44/79 Liselotte Hauer $v$ Land Rheinland-Pfalz [1979] ECR 3727 para 14.

26 Van Gend \& Loos (n 9) 10.

27 Costa/ENEL (n 9) 601.

28 Cf Monica Claes, The National Courts' Mandate in the European Constitution (Hart, Oxford and Portland 2006) 166-186.
} 
Gend \& Loos is the Court's appeal to the direct bond between the Community and the citizens of the Member States. This means that the Community is not only a product of the contracting states, but must also somehow be regarded as the expression of the will of its peoples. Typical in Costa, on the other hand, is the more logic-based emphasis on the importance of unity. The Costa reasoning features high in the justification of autonomy, defended by Rene Barents. ${ }^{29}$ Barents essentially argues that the autonomous nature is inherent in the Treaties. If this were different, EU law would not be able to uphold its uniform character, which, in turn, according to Barents, is a necessary precondition for attaining and maintaining a common market. Even if this argument has a circular ring, it exposes a quality, also apparent in Kadi, that seems crucial for a clear understanding of the notion of autonomy: its self-referential character. That is, in order to realise the objectives set by the Treaties, EU norms can only be judged against their own frame of law. This construction necessitates some kind of ultimate authority. Self-referentiality only makes sense if there is no external normative point of reference and, a fortiori, no external legal authority that can arbitrate on the validity of European norms. Could it therefore be that the principle of autonomy in effect comes down to a disguised claim to sovereignty? ${ }^{30}$

Sovereignty is often considered as a problematic concept in the context of the EU. The reason for this is that the notion appears to be inextricably linked with state-centred thinking. And arguably, the whole concept of European integration was 'invented' to push such tendencies aside. ${ }^{31}$ The main problem of employing sovereignty-based reasoning, however, is that when the notion, as it is traditionally understood, is projected on the ECJ's concept of autonomy, this almost necessarily has to mean that the Member States have lost their sovereign quality. Sovereignty is commonly interpreted as a legal concept with meta-juridical components. ${ }^{32}$ It presupposes a pre-constitutional carrier, a pouvoir constituant. This pouvoir constituant itself is necessarily placed outside the legal order it has brought into being. ${ }^{33}$ Within the legal order, by way of

29 R Barents, The Autonomy of the Community Law (Kluwer Law International, The Hague 2004).

30 See eg Andràs Jakab, 'Neutralizing the Sovereignty Question: Compromise Strategies in Constitutional Argumentation before European Integration and since' (2006) 2 European Constitutional Law Review 375.

31 See Weiler (n 18) 2481.

32 See on the historical development of the notion of sovereignty: Georg Jellinek, Allgemeine Staatslehre, ( $3^{\text {rd }}$ edn Julius Springer Verlag, Berlin 1919) 435-489. On the different aspects of the concept, see Neil Walker (ed), Sovereignty in Transition (Hart, Oxford and Portland 2003).

33 See Hans Lindahl, 'Sovereignty and Representation in the European Union' in Walker (n 32) 87-114. See, from the same author, also: 'Constituent Power and Reflexive Identity: To- 
some kind of representation, the sovereign serves as a device to explain the validity of the norms of the order. This explanation, however, necessitates a certain amount of unity and, accordingly, of hierarchy. Lacking this, there would be no telling how to conceive of the sovereign and how to establish what the content of the common good in a particular polity is. It is for this reason that theories such as 'multilevel constitutionalism', in which sovereignty is attributed to the peoples of the Union but where an ultimate norm or set of norms testifying to this is absent, seem flawed..$^{34}$ Not because it is conceptually unthinkable that the "peoples of Europe' or, for that matter, another clarifying principle could explain and legitimise the authority exercised by the $\mathrm{EU},{ }^{35}$ but because sovereignty, as a fictional and circular concept, needs a constitutional norm or claim that designates a sovereign as sovereign. Without this, there cannot be a people of the Union. A theoretical constellation in which this problem is dodged - ie envisioning a framework with multiple sites of authority with varying corresponding conceptions of the common good - therefore stands on soggy constitutional ground. ${ }^{36}$

A possible way out of this dilemma can be found in theories usually labelled as 'constitutional pluralism'. Regardless of the question of whether or not this is to be called sovereignty, this theory, in its basic form, accepts the claim of the ECJ to ultimate authority of the EU, at least within its sphere of competences, and tries to reconcile this claim with member-state sovereignty. ${ }^{37}$ In doing so, constitutional pluralism es-

wards an Ontology of Collective Selfhood' in Martin Loughlin and Neil Walker (eds), The Paradox of Constitutionalism: Constituent Power and Constitutional Form (OUP, Oxford 2007) 9.

34 See eg Ingolf Pernice, 'Multilevel constitutionalism in the European Union' (2002) 27 European Law Review 51 1, 515-521; Cf also LFM Besselink, Een samengestelde Europese constitutie/A composite European constitution (Europa Law Publishing, Groningen 2007).

35 See in this respect eg Dieter Grimm, 'Does Europe Need a Constitution?' (1995) 1 European Law Journal 282.

36 Adherents of multilevel constitutionalist theories will claim that this critique focuses too much on the paradigm of the unitary state and fails to take into account the experience of federalism which, arguably, also draws on a division of sovereignty over different levels of authority. Cf in this respect eg Stefan Oeter, 'Federalism and Democracy' in Armin von Bogdandy and Jürgen Bast (eds), Principles of European Constitutional Law (Hart, Oxford and Portland 2007) 53. Although this is to a certain extent a matter of definition, it is submitted, however, that federalism, properly understood, is marked by competing conceptions of the common good, that is, by rivaling sources of legal authority. In a federation, one might also argue, the question of sovereignty is suspended. For that reason and in that sense, federalism more closely resembles the paradigm of constitutional pluralism, discussed below.

37 See eg Neil MacCormick, Questioning Sovereignty: Law, State, and Practical Reason (OUP, Oxford 1999); Miguel Poiares Maduro, 'Contrapunctual Law: Europe's Constitutional Pluralism in Action' in Walker (n 32) 501; Neil Walker, 'The Idea of Constitutional Pluralism' (2002) 65 Modern Law Review 317; Mattias Kumm, 'The Jurisprudence of Constitutional Conflict: Constitutional Supremacy in Europe before and after the Constitutional Treaty' (2005) 11 European Law Journal 262; R Barents, 'De voorrang van unierecht in het perspectief van constitutioneel pluralisme' (2009) 58 Sociaal-economische wetgeving 44. 
sentially takes a pan-European view. It argues that both EU and Member States' legal orders, while being in principle completely self-referential, somehow recognise each other's existence and mutual role in a larger European enterprise. As a result, hierarchy has made way for heterarchy. Furthermore, in acknowledging this, so the reasoning goes, their own perceptions of concepts relating to the validity and authority of legal norms have, over time, evolved and, in the name of tolerance, lost their sharp bite. An example of such an advance can be found in, on the one hand, the insertion in the EU Treaty of the "national identity clause' 38 and, on the other hand, integration clauses in national constitutions. ${ }^{39}$ Another illustration, not concerning positive law but judicial practice, provides the well-known Solange saga. ${ }^{40}$ In this line of cases, the German Constitutional Court, while retaining the ultimate competence to strike down European measures in the event of a constitutional conflict, eventually declared that it would trust the ECJ in matters of fundamental rights. Through this dialogue, it can be argued, human rights protection at the level of the EU got a serious boost. What is more, the ECJ on later occasions, most notably in Omega Spielhallen, rewarded the faith invested in the Court by granting protection to national constitutional values. ${ }^{41}$

Taking account of the dynamics at work in European integration and leaving open the 'ultimate arbiter' question, pluralism provides an attractive framework with which to describe the current European constellation. Still, some questions can be raised as to its tenability. First, returning to the validity of the ECJ's concept of autonomy, there is the issue of how to regard the fact that the EU in a fundamental way remains dependent on its constituent parts. Although the EU may have the interpretative Kompetenz-Kompetenz to define the scope of its competences, it does not possess the legislative power to do so. ${ }^{42}$ This power, arguably essential to make a claim to full constitutional authority, still resides with the Member States, who, as a result, can keep calling themselves the Herren der Verträge. ${ }^{43}$ A possible response to this is to maintain that the

\footnotetext{
38 Art 6 (3) EU.

39 Eg art 23 of the German Grundgesetz and art 88-1-88-5 of the French Constitution.

40 BVerfGE 73, 339 [1984] (Solange II).

41 Case C-36/02 Omega Spielhallen [2004] ECR I-9609.

42 See on this difference JHH Weiler and Ulrich Haltern, 'The Autonomy of the Community Legal Order - Through the Looking Glass' (1996) 37 Harvard International Law Journal 423.

43 Cf Udo Di Fabio, 'Der neue art 23 des Grundgesetzes: Positivierung vollzogenen Verfassungswandels oder Verfassungsneuschöpfung?' (1993) 32 Der Staat 191, who remarks, at 201, that Kompetenz Kompetenz 'nichts anderes als eine Konkretisierung von Souveränität ist (...)' ('Kompetenz Kompetenz is nothing but a concretisation of sovereignty' - transl. JWvR). Note with regard to the credibility of the EU's autonomy claim, also the inclusion in Article 50 of the new EU Treaty of a right of withdrawal.
} 
Member States are bound to follow the amendment procedure laid down in Article $48 \mathrm{EU}$, a process that is infused with the enhanced involvement of EU institutions in the new Lisbon Treaty. ${ }^{44}$ This would mean they are no longer pouvoirs constituants, but have become pouvoirs constitués.

Secondly, the question seems relevant to understand how the EU legal order and the legal orders of the Member States relate to each other. Crucially, 'is there law between the heterogeneous legal orders'? ${ }^{45}$ According to a 'radical' pluralist approach, defended by Barents, the relationship between the different legal orders is, due to their self-referential character, purely factual. ${ }^{46}$ As such, there is no European sphere in a normative sense: conflicts have to be solved in a political way. A more moderate account of constitutional pluralism, in contrast, does assume a degree of normative coherence, in the sense that it expects a commitment of the legal actors involved to certain values and principles that help to accommodate mutual interests and avoid conflict. ${ }^{47}$ This means that European pluralism has, to some extent, a limited nature and that there is an overarching normative framework which the various players have to adhere to.

These considerations have one thing in common: they are both concerned with questions that are situated at an internal level; that is, they focus on the EU and the Member States inter se. In light of the outcome in Kadi, more seriously from a practical perspective is how the issue of autonomy unfolds at the level of the international legal order. How does European plurality confront law external to its own order? Does its own particular set-up invite or, in order to remain convincing, even require a similar engagement at other levels? If so, how does one convert the language of values and principles, making up the grease between the adjacent legal orders of Europe, into actual authority? And, if the answer is negative, what does this say about the nature of the internal constellation?

\section{The principle of autonomy in Kadi}

Focusing in the previous section on an exploration of the autonomous nature of the EU from an internal perspective, the external machi-

\footnotetext{
44 See Case 43/75 Defrenne $v$ Sabena [1976] ECR 455 para 58. It could even be argued that the Member States are bound in this procedure by certain material limitations. See in this respect Opinion 1/91 (EEA Agreement) [1991] ECR 6079.

45 'Editorial: “The Law of the Laws" - Overcoming Pluralism' (2008) 4 European Constitutional Law Review 395, 396.

46 R Barents, The Autonomy of the Community Law Chapter 8.

47 Cf eg Kumm (n 37) who approaches pluralism mainly in substantive terms with Maduro (n 37) who takes a more procedural view.
} 
nations of the concept were only briefly touched upon. This is where Kadi comes in. As mentioned, looking to the reasoning in Kadi, the ECJ uses the notion principally to assert the self-referential character of EU law in the face of competing claims of an international nature. Given the autonomous nature of the EU legal order, the Court was not willing to accord special significance to the argument that the contested regulation originated from the international plane. The fact that in this case the international measure that was implemented was not just any rule, but a SC resolution adopted under Chapter VII of the UN Charter, made no difference to the ECJ. Neither did the fact that the content of the resolution effectively left no room for discretion with regard to its implementation. What counted most was 'that measures incompatible with respect for human rights are not acceptable in the Community'. ${ }^{48}$ At first glance, therefore, the principle of autonomy in Kadi functions as a hinge, with the ECJ as locksmith. In the words of Stefan Griller:

while internally stressing the autonomy of the Community legal system serves to preserve (...) a higher derogatory rank vis-à-vis national law, externally it serves to reduce the binding force of international obligations: within the Community they may only be implemented and enforced if properly authorised by the Community legal system. ${ }^{49}$

Kadi involved only the review of the regulation. Because the Community is not a member of the UN - only states are - the ECJ did not consider itself bound by the implementing resolution. For that reason, the latter measure had not become part of the EU legal order. According to the Court, this did not in any way challenge the primacy of the resolution as a matter of international law. ${ }^{50}$ However, the UN Charter, typically for international organisations, does not stipulate how decisions from its institutions should be transposed into domestic law nor does it determine the status thereof at this level. ${ }^{51}$ In the same vein, the ECJ did not show itself to be convinced by the argument that Article $103 \mathrm{UN}$, prescribing the precedence of UN law in the event of conflicting obligations, would entail that binding measures adopted under Chapter VII of the Charter acquired some kind of immunity, ${ }^{52}$ especially since the Treaties do not provide a basis for this. In the opinion of the Court, neither Article 297

\footnotetext{
48 Kadi (n 1) para 284.

49 Stefan Griller, 'International Law, Human Rights and the European Community's Autonomous Legal Order: Notes on the European Court of Justice Decision in Kadi' (2008) 4 European Constitutional Law Review 528, 539.

50 Kadi (n 1) para 288.

51 Kadi (n 1) para 298.

52 Kadi (n 1) para 300.
} 
EC - providing for coordinating steps to be taken by the Member States in order to fulfil obligations relating to the purpose of maintaining peace and international security - nor Article $307 \mathrm{EC}$ - stressing that obligations arising from agreements concluded before 1958 shall not be affected by the Treaties - could derogate from Article $6 \mathrm{EU}$, the embodiment of the values on which the EU is founded..$^{53}$ Finally, the ECJ considered that all this would not be different in the hypothetical situation that the resolution did form part of the EU legal sphere. If the UN Charter was binding on the EU, the Court argued while invoking its case law, it would have a status above secondary law, but still below the level of the Treaties. ${ }^{54}$

In not taking into account the special dimension of the case at hand in its review, the Court effectively barred the EU's gates to the international legal order. It was submitted earlier that the ECJ's reasoning in Kadi, therefore, appears to attest to a dualist view on the relationship between European and international law. Obviously, this does not mean that the Court thinks that the EU does not have to conform to the latter's norms in any way. '(T)he Community's municipal legal order and the international legal order', Advocate General Maduro stated in his Opinion to the case, do not "pass by each other like ships in the night. ${ }^{55}$ Hence, the EU, as an international legal subject, has to respect international law in the exercise of its powers. ${ }^{56}$ Then what does it mean exactly to be characterised as dualist? Just like its counterpart, monism, dualism is notoriously hard to define. ${ }^{57}$ Importantly, the terms seem to relate to two different but connected conceptions on the relationship between legal orders. One view, equating the notions with pluralism and constitutionalism, involves the fundamental question, reminiscent of the debate between Kelsen and Schmitt in the 1920s, on how best to describe the global normative set-up. Is the world a place in which, ultimately, there is some form of legal unity - a Grundnorm upon which all other law is dependent as to its validity? Or is the world, from a normative perspective, an inherently fragmented place in which different sites of constitutional

\footnotetext{
53 Kadi (n 1) paras 301-304.

54 Kadi (n 1) paras 305-308. See also Rass Holdgaard, External Relations Law of the European Community: Legal Reasoning and Legal Discourses (Wolters Kluwer, Alphen a/d Rijn 2008) 173-174.

55 Kadi (n 1) para 22 of the Opinion of A-G Maduro.

56 Kadi (n 1) paras 291-292.

57 See eg John H Jackson, 'Status of Treaties in Domestic Legal Systems: A Policy Analysis' (1992) 86 American Journal of International Law 310; Anne Peters, 'The Position of International Law Within the European Community Legal Order' (1997) 40 German Yearbook of International Law 9; Jan Klabbers, 'International Law and Community Law: The Law and Politics of Direct Effect' (2002) 21 Yearbook of European Law 263; Gráinne de Búrca and Oliver Gerstenberg, 'The Denationalization of Constitutional Law' (2006) 47 Harvard International Law Journal 243.
} 
authority, most notably states, coexist alongside each other? ${ }^{58}$ Another view of monism and dualism is more technical in nature and relates to the question on how international law is received in domestic legal orders. In this respect, one can discern between systems of incorporation, in which international law is received as international law, and systems of transformation, in which, to become valid, international law has to be transposed into domestic law. ${ }^{59}$

The reason why it appears to be relevant to go into this distinction - or, for that matter, into labelling at all - is to be able to compare the ruling of the ECJ with that of the CFI and to judge both decisions on their merits. ${ }^{60}$ The ruling of the CFI in Kadi differs significantly from the judgment of the ECJ. ${ }^{61}$ Where the latter chose to fully review the contested regulation, the former, apart from a somewhat surprising review to ius cogens, essentially judged that its hands were tied. The CFI arrived at this conclusion after having established that both as a matter of international law and as a matter of EU law it had to respect the binding character of the resolution that was at issue. Qua international law, because in light of Article 103 UN the Member States were to accord primacy to norms originating from the UN Charter; an obligation the EU could not interfere with by way of Article 307 EC. ${ }^{62}$ Qua EU law, because the CFI, in contrast to the ECJ, did consider the EU bound by UN law. To that end, it referred to the substitution principle of International Fruit, according to which an international agreement to which the Community is not a party can nonetheless be part of the EU legal order if the Community has replaced the Member States with regard to their commitments under the agreement. ${ }^{63}$ Moreover, in a more fundamental vein, the CFI seemed to be

58 See Hans Kelsen, Pure Theory of Law (transl. from $2^{\text {nd }}$ German edn UCP, Los Angeles 1967); Carl Schmitt, Verfassungslehre (9 $9^{\text {th }}$ edn Duncker \& Humblot, Berlin 1993).

59 Critical: Klabbers (n 57) 294-295.

60 Cataloguing perspectives on the relationship between international law and domestic law as monist or as dualist has become increasingly controversial for being out of touch with the $21^{\text {st }}$ century reality of globalisation. Von Bogdandy, for example, maintains that 'from a scholarly perspective, [monism and dualism] are intellectual zombies of another time and should be laid to rest, or "deconstructed".' (See Armin von Bogdandy, 'Pluralism, Direct Effect, and the Ultimate Say: On the Relationship between International and Domestic Law' (2008) 6 International Constitutional Law Review 397, 401). Although it is true that both notions can be confusing and do not always sit comfortably with the realities of present-day legal practice, they are nevertheless helpful in furnishing two opposite points of a spectrum as regards how to understand the interaction between international law and domestic law.

61 See de Búrca (n 8) 23-37; Griller (n 49) 533-539. Critical on the ruling of the CFI: Christina Eckes, 'Judicial Review of European Anti-Terrorism Measures - The Yusuf and Kadi Judgments of the Court of First Instance' (2008) 14 European Law Journal 74.

62 Kadi (n 3) paras 181-188; Yusuf (n 3) paras 231-238.

63 Kadi (n 3) 203; Yusuf (n 3) 253. See Joined Cases 21-24/72 International Fruit Company $v$ Produktschap voor Groenten en Fruit [1972] ECR 1219. 
of the opinion that a deferential attitude towards UN law also flows from the privileged place of the latter in the international legal order. Invoking amongst others the Vienna Convention on the Law of Treaties and customary international law, the CFI arguably considers the EU somehow to be subordinate to the UN. ${ }^{64}$ So the CFI played its monist card all the way. Not only did it by way of its International Fruit rationale allow UN law to enter the domestic legal order of the EU, it also applied a reasoning in which the autonomy of EU law, in view of the broader global legal order, has a principled limited nature. ${ }^{65}$ In this light, it also becomes easier to understand why the CFI, as its only means of review, took recourse to ius cogens. ${ }^{66}$ As a judicial player in an institutionally decentralised but normatively hierarchical ordered world, it has the power to apply international norms to which even UN organs have to submit. ${ }^{67}$

In sum, it seems that the ECJ and the CFI adopt wholly different perspectives on the nature of the international legal order and the relationship between norms originating from this order and their own domestic law. Whereas the CFI applied an integrated, vertical point of view, the ECJ assumed a segregated, horizontal one, sticking to a notion of autonomy that enables it to approach matters of jurisdiction and validity solely in reference to its own framework of norms. The ECJ has been thoroughly criticised for this, ${ }^{68}$ in particular in view of its earlier case law, in which, so the argument goes, it attested to a fairly moderate monist stance - in the sense that it opened the EU legal order for the effects of

64 Kadi (n 3) paras 221-225; Yusuf (n 3) paras 272-276. See also de Búrca (n 8) 28, 40-43. After Kadi and Yusuf, the CFI to a certain degree attenuated its deferential reasoning on the sanction issue. This was most apparent in Case T-228/02 Organisation des Modjahedines du peuple d'Iran $v$ Council [2006] II-4665 (OMPI $n$ ) in which the Court struck down the listing of the applicant under Council Regulation (EC) no 2580/2001. An important difference between OMPI I on the one hand and Kadi and Yusuf on the other hand, however, was that the SC resolution that led to the adoption of the contested regulation in the former case gave the Member States leeway with regard to the listing of suspected persons and organisations, whereas the resolution in the latter cases expressly provided for this. Although it did not go as far as invalidating the measures that were being disputed, the CFI in another line of sanction cases specified stricter demands with respect to the diplomatic protection to be granted to affected persons at the level of the UN. See on this point $\mathrm{n} 94$.

65 Cf Bjørn Kunoy and Anthony Dawes, 'Plate Tectonics in Luxembourg: The Ménage à Trois Between EC Law, International Law and the European Convention on Human Rights Following the UN Sanctions Cases' (2009) 46 CML Rev 73, 89-92.

66 Kadi (n 3) paras 227-231; Yusuf (n 3) paras 278-282. On the tenability of the CFI's ius cogens review, see: Daniel Halberstam and Eric Stein, 'The United Nations, the European Union, and the King of Sweden: Economic Sanctions and Individual Rights in a Plural World Order' (2009) 46 CML Rev 13, 51-58.

67 Cf Martin Nettesheim, 'UN Sanction against Individuals - A Challenge to the Architecture of European Union Governance' WHI-Paper No 1/07, 22-27 <http://whi-berlin.de/papers/2007.dhtml>.

68 See $\mathrm{n} 8$. 
international law and, thus, developed a line of communication with the outside world. Is this critique justified? The fact is that, partly due to a lack of explicit provisions in the Treaties to that end, it is hard to detect a fully coherent vision on the correlation with external law in the case law of the Court. ${ }^{69}$ This is something that is perhaps not so strange given the peculiar structure of the EU polity. It is true, however, that the ECJ in the past has shown itself to be relatively receptive of international law. Hence, in Haegeman, a case stemming from the mid 1970s, it declared that agreements concluded by the Community under what is now Article $300 \mathrm{EC}$ 'from the coming into force thereof, form an integral part of Community law'. ${ }^{70}$ A couple of years later, in Kupferberg, the Court explained that this mainly had to do with the fact that the Community can be held responsible for the performance of the international obligations it has assumed. ${ }^{71}$ On the same ground, it later extended its reasoning over rules of customary international law and, when it considers itself bound by this, over treaties not concluded by the Community. ${ }^{72}$ With the notable exception of WTO law, the ECJ has also in many instances granted direct effect to international norms, meaning that such norms can be relied upon in front of a European court. ${ }^{73}$ This has to be distinguished from the concept of reception. The fact that a rule of international law is binding upon the Community, and thus an integral part of it, does not automatically mean that such a rule can also be invoked.

Despite its normally open stance, it is important to note, however, that also in the past the Court has always regarded the EU's own constitutional framework as an ultimate point of reference. This is apparent in that on a couple of occasions the Court annulled decisions incorporating

69 For that reason, the European Parliament in 1997 adopted a resolution calling for an explicit mechanism in the Treaties. See 'Resolution on the Relationship between International Law, Community Law and the Constitutional Law of the Member States' [1997] OJ C325/26.

70 Case 181/73 R \& V Haegeman v Belgian State [1974] ECR 449 para 5.

71 Case 104/81 Hauptzollamt Mainz v CA Kupferberg \& Cie KG [1982] ECR 3641 paras 1113. See further Holdgaard 178-181. In Haegeman, the Court had adopted a more formal reasoning, by arguing that the reception of international agreements concluded by the Community followed from its jurisdiction under, now, art $234 \mathrm{EC}$, which, inter alia, provides for references as to the validity and interpretation of acts of the Council. Thus, in this reading, decisions under $300 \mathrm{EC}$ simultaneously count as acts of incorporation. This approach has been criticised by Trevor Hartley, who has argued that agreements and decisions formally concluding such agreements are not the same thing. See Trevor C Hartley, 'The European Court, Judicial Objectivity and the Constitution of the European Union' (1996) 112 LQR 95, 99-100. Critical of this argument: Anthony Arnull, 'The European Court and Judicial Objectivity: A Reply to Professor Hartley' (1996) 112 LQR 411.

72 Case C-162/96 Racke v Hauptzollamt Mainz [1998] ECR I-3655; Cases 21-24/72 International Fruit Company $v$ Produktschap voor Groenten en Fruit [1972] ECR 1219.

73 See generally Piet Eeckhout, External Relations of the European Union: Legal and Constitutional Foundations (OUP, Oxford 2004) Chapter 9. 
international agreements into the EU legal order - both on procedural and on substantive grounds. ${ }^{74}$ Moreover, the autonomous nature of the EU according to the ECJ entails that international law, unless explicitly provided for, cannot derogate from the binding character of the Treaty. In contrast, other allegedly 'self-contained' regimes, such as the WTO, recognise that, in view of their international law character, at the end of the day they have to abide by international law. ${ }^{75}$ Member States of such regimes are within the field of its application generally free to step outside the treaty at hand. Due to the principle of autonomy this is not believed to be possible in the context of the EU, not only as regards the freedom to conclude agreements inter $s e,{ }^{76}$ but for example also when it comes to the issue of jurisdiction. Conflicts concerning the application or the interpretation of the EC Treaty cannot be dealt with via other methods of dispute settlement. ${ }^{77}$ In effect, this all follows logically from the autonomous claim made by the Court in Van Gend \& Loos and Costa/ENEL. When it expressly contrasted the EEC Treaty with 'ordinary international treaties', the ECJ not only cut the EU's umbilical cord with its constituent parts, the Member States, but also untied her 'from the existing legal order of public international law'. ${ }^{78}$ Though this may not be conclusive of the rank of the EU in the global order, the Court's previous case law on the reception of international law, in that sense, was just as dualist as its Kadi decision. Mutatis mutandis, neither can it be said that, compared with earlier cases, the ECJ adopted a very different perspective as regards the mode of reception. Indeed, by not considering the EU bound to the UN Charter, the issue simply did not come up. The critique that with Kadi the Court had exchanged a monist approach for a sharply dualist attitude therefore seems undeserved. If the ECJ's particular line of reasoning is to be criticised, other points should be stressed. ${ }^{79}$

74 See Case C-327/91 France v Commission [1994] ECR I-3641; Case C-122/95 Germany $v$ Council [1998] ECR I-973. See also Kadi (n 1) para 23 of the Opinion of A-G Maduro.

75 See eg Joost Pauwelyn, Conflict of Norms in Public International Law: How WTO Law Relates to Other Rules of International Law (CUP, Cambridge 2003) 87-88. But see Piet Eeckhout, 'Kadi and Al Barakaat: Luxembourg is not Texas - or Washington DC' Blog of the European Journal of International Law of 25 February $2009<$ http://www.ejiltalk.org/kadiand-al-barakaat-luxembourg-is-not-texas-or-washington-dc/>.

76 See eg Opinion 1/91 (EEA Agreement) [1991] ECR 6079. See also Bruno de Witte, The Emergence of a European System of Public International Law: The EU and its Member States as Strange Subjects' in Jan Wouters, André Nollkaemper and Erika de Wet (eds), The Europeanisation of International Law: The Status of International Law in the EU and its Member States (TMC Asser Press, The Hague 2008) 45-48.

77 Case C-459/03 Commission v Ireland [2006] ECR I-4635 (Mox Plant).

78 Kadi (n 1) para 21 of the Opinion of A-G Maduro.

79 See text in notes 97-113. 


\section{Constitutional repercussions}

Sovereignty, Carl Schmitt remarked, is a border concept. ${ }^{80}$ With this description, Schmitt referred to the twilight zone between the factual and the normative, from where, in the event of a political conflict, the true sovereign would appear. In Kadi, it is submitted, the principle of autonomy, whatever its theoretical differences from a classical conception of sovereignty, plays a similar role. By firmly positioning the EU at the external borders of the European legal order, the ECJ, it could be argued, simultaneously affirms the Union's overall claim to authority within that legal order.

As pointed out previously, the ECJ did not think the EU to be bound by the UN Charter. Therefore, the resolution in question did not constitute an integral part of the EU legal order, which, in turn, enabled the Court to review the contested regulation in relative isolation. As the Court implicitly acknowledged in its ruling, this does not diminish the fact that, as a matter of international law, the SC measure remains binding on the Member States. ${ }^{81}$ Could this also mean that the Member States are free or even bound to implement the resolution in their own municipal legal orders? A possible basis for this argument can be found in Article 297 EC and Article 60 (2) EC, which, deviating from the EC Treaty, provide for the adoption of measures necessary for the maintenance of international peace and security. Another, less specific, rationale supplies Article 307 EC, excepting agreements concluded before the entry into force of the Treaty of Rome from the range of EU law. According to A-G Maduro, however, this is not convincing. ${ }^{82}$ Invoking the Court in Centro-Com, he argued that the powers retained by the Member States in the field of the security policy must be exercised in a manner consistent with Community law'. ${ }^{83}$ In light of the unity of the common market, this would also call for respect for fundamental rights. Put differently, by regulating the sanctions regime imposed by the SC in the context of Community law, the EU has exempted the issue from unilateral action on the part of the Member States and, notwithstanding the sensitive nature of the measure and its origins in the CFSP, pulled it into the realm of the first pillar.

\footnotetext{
80 See Carl Schmitt, Politische Theologie: Vier Kapitel zur Lehre von der Souveränität $\left(8^{\text {th }}\right.$ edn Duncker \& Humblot, Berlin 2004) 13.

81 Kadi (n 1) para 288.

82 The Court itself remained largely silent on the possibility of Member States implementing the sanctions unilaterally. See, critically, the annotation on Kadi by Andrea Gattini in (2009) 46 CML Rev 213, 226.

83 Kadi (n 1) para 30 of the Opinion of A-G Maduro, referring to Case C-124/95 Centro-Com [1997] ECR I-81, para 25. See also Robert Schütze, 'On "Middle Ground". The European Community and Public International Law' (2007) EUI Working Paper Law No 2007/13, 17 19 <http://cadmus.eui.eu/dspace/ handle/1814/6817>.
} 
Convincing though this may be, it should be emphasised that this reasoning departs from the viewpoint of EU law. But what about the perspective of the Member States? If the relation between EU law and national law is perceived as being controlled by pluralist dynamics, in which the autonomy of the EU legal order is placed alongside the autonomy of national constitutional orders, this does not seem altogether clear. How far does the commitment of the Member States go? In effect, it could be said that they are caught between two conflicting loyalties. In the first place, of course, loyalty is required towards their obligations under EU law. This follows from several provisions in the Treaties: from the general obligation of Article 10 EC, from a more specific provision like Article 292 EC, but also, for instance, from Article $307 \mathrm{EC}$, which, besides creating a way out of the scope of EU law, calls for eliminating incompatibilities between prior obligations and Community obligations. Secondly, however, there is the duty of the Member States ex Article 103 UN to accord primacy to obligations arising under the Charter. Within the framework of constitutional pluralism, the choice of which loyalty weighs heavier in a case like Kadi cannot be exclusively made by the ECJ. Certainly, the Court is expected to rule as it thinks fit. In addition, it is noteworthy that the ECJ did not overlook the dangers of a legal vacuum resulting from the annulment of the sanction regulation in Kadi and ordered the effects of the contested measure to be maintained for a period of three months, thus enabling the Member States to review their decision and preventing national authorities from possibly implementing the SC resolution independently of the EU. ${ }^{84}$ Still, one of the inherent characteristics of European pluralism appears to be that in matters of existential proportions the ECJ has no ultimate authority to conclusively decide which course the Member States have to follow. This is especially apparent in the case of factual pluralism, as supported by Barents. For, if both the EU and Member States belong to completely self-referential legal orders, with no normative cement in the middle, how is a Member State supposed to respond to a conflicting obligation stemming from a 'third party' that has its own particular claim to supremacy? ${ }^{85}$

Approaching the issue through the lens of normative pluralism is also not without problems. As will be recalled, this brand of constitutional pluralism presupposes the existence of a latent, overarching normative framework: a language of mutual values, so to speak, from which both EU and national players are to deduce answers to conflicting situations

\footnotetext{
84 Kadi (n 1) paras 374-376.

85 Arguably, this would be different if a Member State were to 'constitutionalise' the EU, as for example probably happened in France. See Chloé Charpy, 'The Status of (Secondary) Community Law in the French Internal Order: the Recent Case-Law of the Conseil Constitutionnel and the Conseil d'Etat' (2007) 3 European Constitutional Law Review 436.
} 
that may arise between them. It follows that the ECJ, as a matter of jurisdiction, has no final say as regards the interpretation and application of these principles of values. In theory, this does not have to be an insurmountable problem. Underlying normative pluralism, at least in a substantive way, is the idea that a certain level of coherence is guaranteed through the demand that players on both sides have to adhere to the same higher principles. It does, however, become problematic if more than one principle is in play. As a broader European value, respect for international law seems just as important as respect for fundamental rights. It has been argued that this is only the case if international law carries the promise of 'liberalising' domestic legal orders. ${ }^{86}$ It appears, however, doubtful if this rationale can be accepted: international security constitutes a perfectly legitimate interest.

What to make of this? To begin with, it is possible to argue that Kadi, despite the ECJ's encompassing reasoning, does not necessarily run counter to the concept of constitutional pluralism. Arguably not so much because of the Court's particular fundamental rights rationale, but because of the fact that it was clearly within its jurisdiction to decide on the merits of the case, and that, once within the reach of its competence, one can expect the Court to insist upon a uniform application of EU law. Nevertheless, Kadi also exhibits features that do not sit comfortably with a pluralist conceptualisation. For one thing, there is the overriding importance that the ECJ in its ruling attaches to the rule of law. As Baquero Cruz has pointed out, when it comes to judicial activity and law application, 'any order may decay sooner or later without a minimum degree of predictability with regard to its application'. ${ }^{87}$ Thus, rule-of-law requirements such as legal certainty and individual rights protection, in the end, seem to necessitate a level of hierarchy. And implicit in hierarchy is that someone has the last word. Although not declaring this in so many words, such a sense of hierarchy indeed appears to have been on the Court's mind. This is most apparent in the special treatment the ECJ in Kadi gave to Article $6 \mathrm{EU}$. By stressing that exception provisions such as Article 297 EC and Article 307 EC 'cannot (...) be understood to authorise any derogation from the principles of liberty, democracy and respect for human rights and fundamental freedoms enshrined in Article 6 (1) EU as a foundation of the Union', it effectively lifted this latter provision to a

\footnotetext{
86 See Iris Canor, “Can Two Walk Together, Except They be Agreed?" The Relationship Between International Law and European Law: The Incorporation of United Nations Sanctions Against Yugoslavia Into European Community Law Through the Perspective of the European Court of Justice' (1998) 35 CML Rev 137, 171.

87 See Julio Baquero Cruz, 'The Legacy of the Maastricht-Urteil and the Pluralist Movement' (2008) 14 European Law Journal 389, 414.
} 
'normatively superior category'. ${ }^{88}$ Although it is true that this statement in some ways reflects earlier pronouncements on the limited applicability of Article $307 \mathrm{EC}$, the Court has never been so blunt in derogating from provisions that are themselves primarily to be understood as derogation clauses. ${ }^{89}$

In elevating Article $6 \mathrm{EU}$ as the archimedical point of the EU's legal order, the ECJ seems to leave little room for a pluralist conception of the EU - at least in the sense that there is no arbiter able to decide on the outer perimeters of the larger European normative framework. For, in order to be a veritable Community of law, as the EU purports to be, such an authority is necessary to protect the borders of this framework. Articles $297 \mathrm{EC}$ and $307 \mathrm{EC}$, accordingly, do not function as reserves of sovereignty, capable of competing with that claim, but as exceptions at the will of the Court..$^{90}$ If this were different, as A-G Maduro rightly remarked, Member States could use the Community to circumvent human rights guarantees at a national level. ${ }^{11}$ This is not to claim that the ECJ thinks that values such as fundamental rights are absolute, but it does mean that in the absence of an adequate justification it is not prepared to allow for gaps in the European legal order. ${ }^{92}$ If this understanding is correct, it would in turn entail that, as far as the Court is concerned, the principle autonomy serves as the foundation for a claim to normative authority that encompasses this whole order. The fact that the Member States stay competent to act outside the sphere of the EU, in conceptual terms means little if the latter can decide on the demarcation of that sphere.

Of course, all things considered, the ECJ's firm position in Kadi remains a claim, and as such is only valid until proven otherwise. In addition, most national constitutional courts still do not accept this claim. Finally, there is the already mentioned question of Kompetenz-Kompetenz. The Court's claim to normative authority on behalf of the EU is mainly one of interpretative autonomy; the question of constitutional authority ie who decides who decides - is obscure. For that reason, the EU remains in a state of constitutional flux. Pluralism suggests that this is a good thing, that this is what makes the EU unique. Unquestionably, there is a lot of truth in this: the special institutional set-up, dividing powers between the EU and its Member States, indeed enables a 'mutual cor-

\footnotetext{
88 See de Búrca (n 8) 36. Cf also Armin von Bogdandy, 'Constitutional Principles' in Von Bogdandy and Bast (n 36) 3.

89 Cf Jan Klabbers, 'Moribund on the Fourth of July? The Court of Justice on Prior Agreements of the Member States' (2001) 26 European Law Review 187.

90 Cf Eeckhout (n 73) 440-444.

91 Kadi (n 1) para 31 of the Opinion of A-G Maduro.

92 See eg Case C-84/95 Bosphorus Hava Yollari Turizm ve Ticaret AS v Minister for Transport, Energy and Communications [1996] ECR I-3953 para 21.
} 
rection of each other's constitutional malfunctions'. ${ }^{93}$ The point rather is that Kadi shows how difficult it is to maintain such an equilibrium in the face of fundamental questions being imposed upon the EU's special constitutional structure from outside its cocoon. In the end, concerns for the rule of law and uniformity win the day.

\section{Alternatives}

As a final question, could Kadi have been decided in a way to show more respect for pluralistic constitutional principles? At first glance, the CFI came closer to this than the ECJ. After all, respect for diversity of sources within a constitutional configuration also seems to suggest a certain reverence for sources outside that formation. Indeed, one could argue that taking constitutional pluralism seriously entails that different orders are by implication interlinked and, hence, that autonomy is by definition a limited concept. It is submitted, though, that the CFI fails this test. For one thing, it is not at all clear that this court's open attitude vis-à-vis international law translates into a corresponding posture in the internal European order. The ruling of the CFI even points in the opposite direction. By stressing that the Charter imposes a clear obligation upon the Member States and, save a ius cogens test, by immunising the resolution as a matter of EU law, the CFI, by way of the principle of supremacy, effectively appears to bar the door to judicial review by national courts. ${ }^{94}$ This may be said to follow logically from the assumption that the

93 Maduro (n 37) 523.

94 See Eckes (n 61) 87. The only redress that the CFI envisages is the trajectory of diplomatic protection, ie Member States bringing up cases of affected nationals for delisting in front of the UN Sanctions Committee. See Kadi (n 3) para 270; Yusuf (n 3) para 317. In later sanctions cases, the CFI even appears to formulate a communitarian obligation on the part of the Member States to enable its nationals to present their cases before the Sanctions Committee. See Case T-253/02 Chafiq Ayadi v Council [2006] ECR II-2139 paras 144-148; Case T-49/04 Faraj Hassan $v$ Council and Commission [2006] ECR II-52 paras 119-122. Critical of this reasoning are Kunoy and Dawes (n 65) 92-96, who assert that diplomatic protection, being a traditional international law tool in the hands of states, cannot be conceived as an obligation. Anyway, diplomatic protection, however framed, is no up-to-par equivalent of judicial or administrative review by national authorities, who, upon finding a violation of national fundamental rights, could order a government to unblock funds. An, admittedly rare, example of such an action has recently been provided by a Belgian court, which threatened to impose a considerable fine on the government if it failed to unlock the financial assets of the plaintiff whom the court considered to be unjustly accused of ties with terrorist organisations. (See Nabil Sayadi and Patricia Vinck, Judgment of 11 February 2005, RG 2004/2435-A IA/26834-A (Brussels Court of First Instance)). The Belgian government thereupon initiated proceedings at the UN Sanctions Committee to get the applicant's name delisted, although so far without success. The Sayadi case, therefore, at the same time serves to show that remedies in domestic courts often have a limited nature and that obtaining a court order is not necessarily the end of the story. Compare in this respect the views of the UN Human Rights Committee of 29 December 2008, Communication No $1472 / 2006$, in the same case, which, although confirming the duty of the Belgian state to 
international legal order is somehow coherent, hierarchical, and that UN law, because of its higher rank, has to be abided by. In the absence of an international authority capable of maintaining such coherence, however, there is the inherent danger that this order will disintegrate. By empowering itself to review actions of institutions outside its natural habitat with norms that equally originate from outside its own legal order, the jurisdiction of the CFI becomes theoretically unlimited. It could be argued that this is a desirable development and that within a paradigm of 'open functionally interlinked and mutually constraining entities' the effectiveness of and compliance with international law is enhanced, even to the extent that this leads to a 'constitutionalisation' of the latter. Then again, if other courts followed the example of the CFI, there would be the risk of diverging outcomes, so that instead of leading to constitutionalisation it would only enhance fragmentation of international law. ${ }^{95}$

If the CFI's vision is to be discarded as a viable alternative, does this mean in turn that the 'robust pluralist' reading of the ECJ has to be accepted, and, a fortiori, that there is no international legal order in an autonomous sense, but only separate entities drifting in an ocean of derivative normativity? Denouncing Kelsen's claim of a world constitution, Schmitt in this regard observed that the concept of an international community constituted 'nur der Reflex der Koexistenz selbständiger politischer Einheiten'. ${ }^{96}$ For this reason, international law could not really be termed law. This may have been conceivable in the 1920s, but in today's post World War II global era it seems hardly acceptable. Most importantly, it can also not actually be presumed that the ECJ embraces this view. Accordingly, the question becomes whether it is possible for the ECJ to simultaneously preserve the autonomy of the EU and still be more open to international law than it was in Kadi. Drawing on de Búrca, a potential way out can be found in the strategy of 'soft constitutionalism'. ${ }^{97}$ In short, a soft constitutionalist approach comes down to a Kantian understanding of the international legal order in which states and other like entities coexist in a heterarchical manner, but at the same time aspire to live up to common and universal norms with which to address conflict. Soft constitutionalism, therefore, appears to be very much akin to European normative pluralism, with the only real difference being the scale on which such norms can be found.

pursue the delisting of the applicant, was divided as regards the extent of the responsibility of a state to secure this.

95 Nettesheim (n 67) 24-25.

96 Schmitt (n 58) 73 ('... only the reflex of the coexistence of autonomous political entities' - transl. JWvR).

97 See de Búrca (n 8) 52-55. Cf also Pavlos Eleftheriadis, 'Cosmopolitan Law' (2003) 9 European Law Journal 241. 
According to this strategy, the ECJ, instead of addressing the issue in Kadi exclusively in terms of EU fundamental rights, could have pulled international legal standards - customary international law, the Charter into the discussion. For example, it could have done so by focusing on the lack of due process at the moment of implementation of the resolution into European law. ${ }^{98}$ As such, it is argued, the Court would have been able to contribute to an international debate and involve national actors, while achieving the same substantive result. Secondly, one can think of the Solange doctrine of the German Constitutional Court. ${ }^{99}$ As stated earlier, in this well-known chapter of European integration, the Bundesverfassungsgericht, on a couple of occasions, entered into a dialogue with the ECJ on the protection of fundamental rights in the Community. This test, which has recently also been applied by the European Court of Human Rights (ECtHR) vis-à-vis the EU, can be said to be performed through an open window between two, mutually linked, legal orders. ${ }^{100}$ Thus, the result would be a blend of shared values. Arguably, A-G Maduro came close in applying some kind of Solange reasoning in his review of the alleged breaches of fundamental rights in Kadi. Although Maduro in the end considers the level of protection at the UN too inadequate to bow to its authority, ${ }^{101}$ he did take notice of the fact that 'the Court should be mindful of the international context in which it operates' and that in 'an increasingly interdependent world, different legal orders will have to endeavour to accommodate each other's jurisdictional claims'. ${ }^{102}$ The ECJ, however, seems to decline to develop such a test. Asked if the re-examination procedure before the Sanctions Committee - the ancillary organ of the SC responsible for overseeing the sanctions - did not amount to a sufficient legal remedy, the Court responded, in a seemingly general way, that this could not 'give rise to a generalised immunity from jurisdiction within the internal legal order of the Community', because that 'procedure does not offer the guarantees of judicial protection.' ${ }^{103}$

Soft constitutionalism is based on the premise that the EU is somehow able to open up for UN law. At first glance, earlier case law of the ECJ indeed suggests that this is possible. Most notably in Bosphorus, a case that dealt with sanctions applied in the context of the war in former Yugoslavia, the Court showed no restraint in referring and interpreting the SC resolution which constituted the basis for the contested regula-

98 de Búrca (n 8) 57-58.

99 de Búrca (n 8) 58-61. See also Griller (n 49) 544-545.

100 See ECtHR, Bosphorus Hava Yollari v Ireland [2006] EHRR 42.

101 Kadi (n 1) para 54 of the Opinion of A-G Maduro.

102 Kadi (n 1) para 44 of the Opinion of A-G Maduro. See also Halberstam and Stein (n 66) 58-61.

103 Kadi (n 1) paras 321-322. 
tion. ${ }^{104}$ However, just as in Kadi, the ECJ did not consider the resolution at issue to be binding upon the EU. The measure also did not form an integral part of the Community legal order. From a formal point of view, this seems strange. How could the ECJ seek recourse to an external rule if it was not part of the EU legal order? ${ }^{105}$ Looking to Haegeman and Kupferberg, one gets the impression that being an 'integral part of Community law' is inextricably linked with the binding nature of an international measure. ${ }^{106}$ Therefore, it could be argued that the question of reception does not prevent the Court from being able to reach out to international law for interpretative purposes. This appears to be confirmed by the extensive way the ECJ in its case law refers to the European Convention of Human Rights (ECHR). ${ }^{107}$ The ECHR, though not (yet) formally binding upon the EU, has served as a source of inspiration for the Community since the early 1970s, ${ }^{108}$ something that was expressly allowed by the inclusion in the Treaty of Maastricht of a reference to the human rights treaty. ${ }^{109}$ Indeed, on some occasions, the ECJ even directly resorted to a provision of the ECHR. ${ }^{110}$

Why, then, did the ECJ emphasise that UN law could not be used in Kadi? Why did it not refer to UN human rights standards in an interpretative way? A straightforward answer would be that this would not have been relevant in Kadi. First of all, the disputed resolution, in contrast, for example, to Bosphorus, left no room for manoeuvre as to its implementation. Secondly, one could argue that UN law did not really conflict with EU law in Kadi; that is, the question whether Member States are obliged, under EU law, to provide for review of decisions listing individuals under the sanctions regime is in principle unrelated to the question whether they are obliged, under UN law, to implement anti-terrorism sanctions. ${ }^{111}$ Furthermore, the UN Charter, unlike the ECHR, is not a human rights instrument, and even to the extent that it can be considered as such, it does not provide the same level of protection as the ECHR or the EU's own general principles. In this regard, more fundamental could be the fact that the Charter, because of its different character from the ECHR, is not suited just to serve as an interpretative instrument. The Charter

\footnotetext{
104 See $\mathrm{n} 92$.

105 See $n 59$.

106 See ns 70-71.

107 See generally Sionaidh Douglass-Scott, 'A Tale of Two Courts: Luxembourg, Strasbourg and the Growing European Human Rights Acquis' (2006) 43 CML Rev 629.

108 See Case 4/73 Nold v Commission [1974] ECR 491.

109 See art 6 (2) EU juncto art 46 (d) EU.

110 See eg Case C-112/00 Schmidberger [2003] ECR I-5659.

111 See Nikolaos Lavranos, 'UN Sanctions and Judicial Review' in Wouters, Nollkaemper and de Wet (n 76) 194-195.
} 
is the constitution of an organisation that comprises institutions which can issue binding legislative measures. Therefore, the only alternative in front of the Court might have been to opt for the substitution rationale of International Fruit, which was applied by the CFI. Apart from the question about whether or not this reasoning is convincing, ${ }^{112}$ within the confines of the ECJ's understanding of autonomy, this would have meant that the Charter, as an integral part of the Community legal order, would have been placed below EU law, which a correct reading of Article 103 UN also seems to allow. ${ }^{113}$ Not only is this not without political significance, it also raises important questions as regards the legal effects of such a move. Would this, for example, mean that resolutions or the Charter could be invoked within the field of application of EU law, or that, in a hypothetical situation, the Court could disapply UN law?

In sum, the Court in Kadi faced a difficult choice. By opening the EU legal order up to UN law, on one hand the ECJ would have created a window of opportunity to discuss human rights in a global context and, thus, influence this debate. Speaking out on this, however, would have entailed the risk of binding the EU to a category of law, with consequences that would possibly outweigh the advantages of a more communicating posture. In this regard, it will be interesting to see how the Court responds to the new Lisbon Treaty, which, in Article 3 (5) EU, stipulates that the EU will honour the principles of the UN Charter. Moreover, even with this inclusion, it remains uncertain how the ECJ will react to future challenges similar to those in Kadi. Inherent, for example, in the Solange approach, it seems that the Court will have to differentiate between measures with a purely domestic character and measures that originate outside the legal order. Is it prepared to lower the threshold of fundamental rights protection, and consequently the rule of law, for the benefit of international law? Indeed, if the ECJ were to lower this threshold, it might also paradoxically run the risk of seeing certain national constitutional courts retract their particular Solange statements vis-à-vis the EU.

If, on the other hand, the ECJ persists in its dualist attitude towards international law, its case law might become self-defeating, for then it could be argued that it does not live up to the promise of Europe's normative appeal to the world, especially given that the EU itself remains largely unchecked in the face of its legal surroundings. This can be seen most clearly in the case law of the ECtHR, which, in the absence of formal jurisdiction over the EU, is very careful in reviewing acts that stem from Brussels. ${ }^{114}$ In this sense, it is a good thing that, under the Lisbon Treaty,

112 See Eeckhout (n 73) 437-440.

113 See Nettesheim (n 67) 23.

114 The ECtHR lingers between a Solange approach (n 99) and focusing solely on the challenged Member State (Matthews v United Kingdom [1999] BHRC 686 (ECtHR)). 
the EU will accede to the ECHR. ${ }^{115}$ Since the dilemma the ECJ saw itself confronted with in Kadi under this new constellation would eventually only be transposed to another level, it does, however, not solve the problem as such. ${ }^{116}$

\section{Conclusion}

There is a certain irony in the different findings of the CFI and the ECJ in the Kadi case. The CFI, on one hand, applied a reasoning that was itself very open to the international legal order, but in the end arrived at a conclusion that, instinctively, let this order down. The ECJ, on the other hand, employed a rationale that arguably eschewed international law, but came up with an outcome that on the face of it must have fulfilled human rights activists across the globe with joy. Although the ECJ has been criticised for being overtly dualist, its stance seems however better defensible than that of the CFI. Departing from the premise that the EU constitutes an autonomous legal order, the Court understandingly asserted that the own legal order formed its frame of reference. The conceptual tenability of the principle of autonomy as such is, almost half a century after its creation, still not without problems. When this claim is accepted, however, it follows logically that the ECJ was under no obligation to accord primacy to international law over the EU's primary law. The fact that Kadi involved UN law does not change this. In contrast to the CFI, which approached the international legal order in universalist terms, the Court was right to embrace a pluralist point of view in this regard. Abandoning a self-referential perspective, admirably though it may seem, could in the long term be disruptive. This is not to say that international law can be disregarded at will or, for that matter, that there is no such thing as an international community. Autonomy, like sovereignty, is not necessarily a notion hostile to international law. In a way, both concepts resemble a chicken-and-egg story: they presuppose each other. In Kadi, the Court chose to let concerns for the rule of law prevail over concerns for international law. Given the particular situation of the case, this choice was a legitimate one. It does not, however, signify that the ECJ embarked on a whole new trajectory as regards its views on the relationship of the EU with the international legal order.

As a second conclusion, it was submitted in this paper that the attitude of the ECJ vis-à-vis the international plane has consequences for, that is, it sheds light on, the way the internal set-up of the EU should be perceived. In the process of defending the autonomy of the EU legal order

\footnotetext{
115 Art 6 (2) EU.

116 Cf Apps no 71412/01 \& 78166/0 Behrami and Behrami $v$ France \& Saramati $v$ France, Germany and Norway ECtHR 2 May 2007.
} 
in an external sense, the Court at the same time makes clear that it is difficult to maintain that the foundations of the broader European legal order are pluralistic in nature. In order to be a veritable Community of law, a gatekeeper is needed to patrol the borders of this order and uphold unity therein. In this sense, and notwithstanding the theoretical difficulties that arise from such a conception, the principle of autonomy entails that EU law, in particular the values upon which it is founded, outranks national law. To be sure, in light of the diverging explanations as to the validity of EU law, it might well be that the paradigm of constitutional pluralism to a certain extent reflects the current status of the European constitutional configuration in a descriptive way. However, as a theoretical framework that purports to provide answers with respect to the inherent nature of European constitutionalism, it falls short. 